\title{
Biomass Yield, Chemical Composition and Potential Ethanol Yields of 8 Cultivars of Napiergrass (Pennisetum purpureum Schumach.) Harvested 3-Monthly in Central Thailand
}

\author{
Kannika Rengsirikul ${ }^{1}$, Yasuyuki Ishii ${ }^{2}$, Kunn Kangvansaichol ${ }^{3}$, Prapa Sripichitt ${ }^{1}$, \\ Vittaya Punsuvon $^{4}$, Pilanee Vaithanomsat ${ }^{5}$, Ganda Nakamanee ${ }^{6}$, Sayan Tudsri ${ }^{{ }^{*}}$ \\ ${ }^{1}$ Faculty of Agriculture, Kasetsart University, Bangkok, Thailand \\ ${ }^{2}$ Faculty of Agriculture, University of Miyazaki, Miyazaki, Japan \\ ${ }^{3}$ PTT Public Company Limited, Ayutthaya, Thailand \\ ${ }^{4}$ Faculty of Science, Kasetsart University, Bangkok, Thailand \\ ${ }^{5}$ Kasetsart Agricultural and Agro-Industrial Product Improvement Institute, Bangkok, Thailand \\ ${ }^{6}$ Nakhonratchasima Animal Nutrition Research and Development Center, Nakhonratchasima, Thailand \\ Email: ${ }^{*}$ agrsat@ku.ac.th
}

Received March 20, 2013; revised April 21, 2013; accepted May 15, 2013

Copyright (c) 2013 Kannika Rengsirikul et al. This is an open access article distributed under the Creative Commons Attribution License, which permits unrestricted use, distribution, and reproduction in any medium, provided the original work is properly cited.

\begin{abstract}
Eight cultivars of napiergrass (Pennisetum purpureum Schumach.), namely Dwarf, Muaklek, Bana, Taiwan A148, Common, Wruk wona, Tifton and Kampheng San, were grown in central Thailand in 2008-2009 and biomass yield, chemical composition and theoretical ethanol yield were measured. Harvests were made every 3 months. Biomass yield and cell wall compositions differed significantly $(P<0.05)$ among cultivars. Tifton produced the highest annual biomass yield at $58.3 \mathrm{t} / \mathrm{ha}$ followed by Wruk wona ( $52.1 \mathrm{t} / \mathrm{ha}$ ), while the lowest yield of $27.1 \mathrm{t} / \mathrm{ha}$ was in Dwarf. Biomass yield varied with season with highest yields in May and lowest in February during the dry season. Cell wall concentrations were higher in the tall cultivars than in the short ones (Dwarf and Muaklek) $(P<0.05)$. Theoretical ethanol conversion efficiency ranged from 350 to $460 \mathrm{~L} / \mathrm{t} \mathrm{DM}$ among the cultivars following pretreatment with steam explosion. While a number of cultivars showed significant potential for use as biofuels in central Thailand, Tifton seemed to be the most promising.
\end{abstract}

Keywords: Bioenergy; Biomass Yield; Cultivar; Pennisetum purpureum; Season

\section{Introduction}

Energy resources in Thailand have been greatly reduced in the last 10 years [1], and the demand has been satisfied mainly by imported fuels such as natural gas, charcoal and oil. Meanwhile, rapid industrial and commercial growth in recent decades has led to an increasing energy demand in Thailand. Therefore, the increasing world prices for fossil fuels have led to an escalation in the price of Thai products. The development of alternative energy sources should solve this problem. Although vegetable biomass is the biggest supplier of renewable energy in the developing world, it contributes only $4 \%$ of the total fuel supply in Thailand [2]. In the central part of

"Corresponding author.
Thailand where soil fertility is higher than in other regions, the genus Pennisetum (including napiergrass) contains the most productive tropical grasses. Even with frequent cutting, this genus outyielded other tropical grasses such as paragrass, guineagrass and ruzigrass [3-5]. Many cultivars from this genus are commonly grown for animal feed, and Common napier, King napier, Bana, Wruk wona, Merkeron and the short type (Mott dwarf) can produce biomass yields exceeding $25 \mathrm{t} / \mathrm{ha} / \mathrm{yr}$ dry matter (DM) when cut at 30-day intervals [6]. At Pak Chong in central Thailand, biomass yield reached $75 \mathrm{t} / \mathrm{ha} / \mathrm{yr}$ when cut at 60-day intervals [3]. Yields of this magnitude make napiergrass a promising species for methane generation or for co-firing with coal to produce electricity. In Thailand, there is considerable interest in the potential 
use of napiergrass to produce ethanol. Napier cultivars currently in use were selected for use as animal feeds, with emphasis on high leaf percentage, high $\mathrm{N}$ concentration and low fiber levels. Dry matter yield was often sacrificed to obtain high feed quality. In contrast, for bioenergy production, the object is to obtain maximum yield of biomass, with quality suitable for either direct combustion or ethanol conversion [7,8]. Therefore, the objectives of this paper were to quantify the yield and quality of biomass produced in different seasons by a range of napiergrass cultivars when cut at 3-monthly intervals throughout the year and to assess their potential as a source of energy for ethanol and solid biofuel production in central Thailand.

\section{Materials and Methods}

\subsection{Experimental Site}

The experiment was carried out at Suwanvajokkasikit Research Station, Pak Chong, Nakhonratchasima, Thailand situated at $14^{\circ} 38^{\prime} \mathrm{N}, 101^{\circ} 18^{\prime} \mathrm{E}$ and $388 \mathrm{~m}$ above sea level in April 2008-May 2009. The soil was sandy clay loam with moderate fertility and $\mathrm{pH}$ of 6.5 (in water). Chemical composition of the top $0-15 \mathrm{~cm}$ of soil was 13 - $14 \mathrm{ppm}$ of available phosphorus (P), 78 - $160 \mathrm{ppm}$ of available potassium $(\mathrm{K})$ and $1.21 \%-1.74 \%$ of organic matter, using the in-house method based on AOAC [9] and OMAF [10] methods were determined by the laboratory of the Department of Agriculture, Thailand. Daily rainfall was recorded at the Pak Chong Meteorological Station.

\subsection{Experimental Design}

A randomized block design was employed with 8 napiergrass cultivars namely; Bana (BN), Taiwan A148 (TW), Common (CM), Wruk wona (WW), Tifton (TT) and Kampheng San (KS), representing tall types, and Dwarf (DW) and Muaklek (ML), representing short type and four replications.

\subsection{Experimental Procedure and Plant Measurements}

The area was ploughed and cultivated to produce a firm fine nursery bed before planting on 10 April 2008. Rooted tillers of all cultivars were grown in plastic trays in the nursery for 4 weeks prior to transplanting into the experimental area. The transplanted grasses were grown at $75 \times 75 \mathrm{~cm}$ spacing. Individual plots consisted of five $6.0 \mathrm{~m}$ rows spaced $0.75 \mathrm{~m}$ apart, giving 40 plants per plot. An initial basal fertilizer dressing of 15-5-20 (N-P-K, \%) at the rate of $160 \mathrm{~kg} / \mathrm{ha}$ was applied on 10 April 2008. Nitrogen as urea fertilizer was applied after each harvest to provide nitrogen at $375 \mathrm{~kg} / \mathrm{ha} / \mathrm{yr}$. All plots were cut on
29 May 2008 to commence the observation period and the material discarded. Subsequent harvests were made on 29 August 2008, 29 November 2008, 28 February 2009 and 29 May 2009. In each plot, plant height was measured from an area of $1.50 \times 2.25 \mathrm{~m}$ (6 plants) at the day of cutting. Tiller density was also determined by counting the plant in an area of $1.5 \times 3.0 \mathrm{~m}$ in each plot at the same day of cutting. Forage on a central area of $2.25 \times 3.00 \mathrm{~m}$ (12 plants) in each plot was cut at $15 \mathrm{~cm}$ above ground level and fresh weight recorded. A $500 \mathrm{~g}$ sub-sample was taken, separated into leaf and stem components, dried at $60^{\circ} \mathrm{C}$ for 72 hours and dry weight was recorded. Samples collected in August 2008 and February 2009 were ground to pass a $1 \mathrm{~mm}$ screen and analyzed for, carbon $(\mathrm{C})$, hydrogen $(\mathrm{H})$, oxygen $(\mathrm{O})$, nitrogen $(\mathrm{N})$ and sulfur (S) by using an elemental analyzer (CHNS analyzer, LECO, MI, USA). Cellulose, hemicelluloses and lignin concentrations were determined by the detergent method [11] and heating value by using a bomb calorimeter [9]. Samples from one replication from the August 2008 harvest were analyzed for glucose content. About $100 \mathrm{~g}$ dry matter (DM) of sample was cut to an average length of $2.5-3.5 \mathrm{~cm}$, and soaked in $125 \mathrm{~mL}$ of water for $10 \mathrm{~min}$. Steam explosion was carried out in a 2.5 litre steam explosion apparatus (Nitto Koatsu Co. Ltd, Japan) under pressure of $14 \mathrm{~kg} / \mathrm{cm}^{2}$ at $200^{\circ} \mathrm{C}$ for $5 \mathrm{~min}$. The exploded material was then filtered into solid and liquid components, and kept in sealed plastic bags at $4^{\circ} \mathrm{C}$ until glucose analysis. The objective of pretreatment was to remove lignin from cellulose and hemicelluloses prior to glucose analysis. The glucose content was determined by the HPLC system (Shimadzu, Kyoto, Japan) at $80^{\circ} \mathrm{C}$ in an Aminex HPX-87P column (Bio-Rad, Sunnyvale, CA, USA), attached with a refractive index detector, with deionized water at a flow rate of $0.6 \mathrm{~mL} / \mathrm{min}$. Theoretical ethanol yield was calculated by using the Theoretical Ethanol Yield Calculator software provided by US Department of Energy [12].

\subsection{Statistical Analysis}

All data except for glucose content and ethanol yield were tested for significance at $P<0.05$ level by the new Duncan's Multiple Range Test.

\section{Results}

\subsection{Rainfall}

Figure 1 showed a period of low rainfall between November and February and a wet season from March to October with distinct peaks in April-May and September. When the grasses were establishing in April 2008, soil was quite moist owing to moderate rainfall in this month plus $177 \mathrm{~mm}$ of irrigation at planting. Sprinkler irrigation 


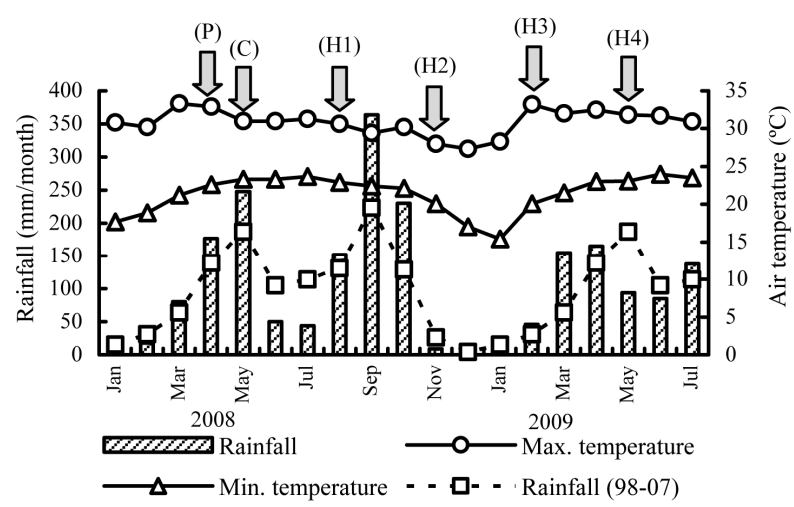

Figure 1. Monthly rainfall and air temperature in 20082009 and the average of the previous 10 years in 1998-2007, (P) Planting; (C) Common cutting; (H1-H4) Harvesting.

was applied at $40 \mathrm{~mm}$ twice a month ( $80 \mathrm{~mm} / \mathrm{month})$ in June and July. Dry and cool conditions reduced grass growth in December, January and February.

\subsection{Plant Length and Tiller Number}

Plant length prior to harvest and tiller number differed between cultivars and seasons $(P<0.05)$. In general, tall cultivars reached a greater length (2 to $4 \mathrm{~m}$ ) than Dwarf $(<1 \mathrm{~m})(P<0.05)$ with Muaklek intermediate. Tall cultivars were 3 to $4 \mathrm{~m}$ tall in August, November and May and 2 to $2.5 \mathrm{~m}$ in February. Tiller numbers tended to be the mirror image of height with Dwarf showing more tillers (300 to 500 tiller $\left./ \mathrm{m}^{2}\right)$ than tall cultivars $(<50$ tiller/ $\left.\mathrm{m}^{2}\right)$, with tiller numbers peaking in February $(P<0.05)$ in all cultivars, with the effect most pronounced in Dwarf.

\subsection{Biomass Yield (DM)}

Annual biomass yield differed significantly $(P<0.05)$ among cultivars (Table 1). The tall cultivars yielded 46.3 - $58.4 \mathrm{t} / \mathrm{ha} / \mathrm{yr}$ compared with 27.1 and $35.1 \mathrm{t} / \mathrm{ha} / \mathrm{yr}$ for Dwarf and Muaklek, respectively. Yields varied with season in all cultivars with an overall pattern of highest yields in May and lowest in February $(P<0.05)$.

\subsection{Concentrations of Cell Wall Components (Cellulose, Hemicellulose and Lignin)}

In the rainy season (August), cellulose concentrations in stem exceeded that in leaves $(36.8 \%-52.6 \%$ vs $32.7 \%$ 37.8\%) $(P<0.05)$.

Tifton had the highest concentration (52.6\%) in stems. Cellulose concentrations in total dry matter ranged from $35.4 \%$ in Dwarf to $47.3 \%$ in Tifton $(P<0.05)$ (Table 2$)$.

In the dry season (February), cellulose concentration in whole plant samples ranged from 34.4\% (Dwarf) to $46.7 \%$ (Tifton) $(P<0.05)$.In general, the two short-type cultivars had lower cellulose concentrations than the taller cultivars (Table 2). Conversely, concentrations of
Table 1. Yield distribution and annual dry matter (DM) yields of 8 napiergrass cultivars.

\begin{tabular}{|c|c|c|c|c|c|}
\hline \multirow[b]{2}{*}{ Cultivar } & \multicolumn{4}{|c|}{ Dry matter yield (t/ha) } & \multirow[b]{2}{*}{ Total } \\
\hline & $\begin{array}{l}\text { 1st harvest } \\
\text { (29/08/08) }\end{array}$ & $\begin{array}{l}\text { 2nd harvest } \\
(29 / 11 / 08)\end{array}$ & $\begin{array}{l}\text { 3rd harvest } \\
(28 / 02 / 09)\end{array}$ & $\begin{array}{l}\text { 4th harvest } \\
\text { (29/05/09) }\end{array}$ & \\
\hline DW & $6.6^{\mathrm{e}}$ & $6.9^{\mathrm{d}}$ & $4.1^{\mathrm{cd}}$ & $9.5^{\mathrm{c}}$ & $27.1^{\mathrm{e}}$ \\
\hline ML & $7.3^{\mathrm{e}}$ & $9.5^{\mathrm{c}}$ & $3.4^{\mathrm{d}}$ & $15.1^{\mathrm{b}}$ & $35.1^{d}$ \\
\hline $\mathrm{BN}$ & $13.6^{\mathrm{c}}$ & $15.5^{\mathrm{a}}$ & $4.5^{\mathrm{cd}}$ & $15.5^{\mathrm{b}}$ & $49.1^{\mathrm{bc}}$ \\
\hline TW & $14.6^{\mathrm{bc}}$ & $15.4^{\mathrm{a}}$ & $6.3^{\mathrm{ab}}$ & $15.2^{\mathrm{b}}$ & $51.5^{\mathrm{b}}$ \\
\hline $\mathrm{CM}$ & $16.0^{\mathrm{ab}}$ & $13.3^{\mathrm{b}}$ & $6.7^{\mathrm{a}}$ & $15.3^{\mathrm{b}}$ & $51.4^{\mathrm{b}}$ \\
\hline WW & $13.6^{\mathrm{c}}$ & $15.8^{\mathrm{a}}$ & $4.9^{\mathrm{bcd}}$ & $17.8^{\mathrm{ab}}$ & $52.1^{\mathrm{b}}$ \\
\hline $\mathrm{TT}$ & $17.2^{\mathrm{a}}$ & $15.6^{\mathrm{a}}$ & $6.7^{\mathrm{a}}$ & $18.8^{\mathrm{a}}$ & $58.4^{\mathrm{a}}$ \\
\hline KS & $10.9^{\mathrm{d}}$ & $13.3^{\mathrm{b}}$ & $5.1^{\mathrm{bc}}$ & $16.8^{\mathrm{ab}}$ & $46.3^{c}$ \\
\hline Avg. & 12.5 & 13.2 & 5.2 & 15.5 & 46.4 \\
\hline
\end{tabular}

Means in each column with the same letter are not different at $P<0.05$.

hemicelluloses in leaf were higher than in stem for all cultivars. In the rainy season, concentrations in leaf ranged from $24.6 \%$ to $27.6 \%$, while concentrations in stem ranged from $15.9 \%$ to $25.1 \%$, with no significant difference between cultivars. Concentrations in whole plant samples ranged from $19.3 \%$ in Tifton to $26.4 \%$ in Muaklek $(P<0.05)$ (Table 2).

In the dry season, differences between taller and shorttype cultivars tended to decline with both the highest (Wruk wona at 25.9\%) and lowest (Tifton at 19.5\%) concentrations of hemicelluloses being found in taller cultivars. In general, lignin concentrations in leaf were lower than in stem with mean values of $8.0 \%$ and $11.0 \%$, respectively, over all cultivars in the rainy season. Similarly, short-type cultivars generally contained lower lignin concentrations than taller cultivars (Table 2), with the effect being more pronounced in the rainy season. Concentrations in whole plant samples ranged from $5.6 \%$ in Dwarf to $12.3 \%$ in Tifton $(P<0.05)$ in the rainy season and $4.4 \%$ (Dwarf) to $7.8 \%$ (Tifton) in the dry season $(P<0.05)$.

\subsection{Concentrations of Elements (C, H, O, N, S) and Ash}

In both seasons, short-type cultivars had higher concentrations of $\mathrm{O}$ and $\mathrm{N}$ and lower concentrations of $\mathrm{C}$ and $\mathrm{H}$ than the taller cultivars (Table 3).

In general, $\mathrm{C}$ concentrations in harvested material declined from wet to dry seasons while $\mathrm{H}$ and $\mathrm{O}$ concentrations increased. Ash concentrations ranged from 7.7\% (Taiwan A148) to $11.6 \%$ (Muaklek) $(P>0.05)$ in the rainy season, while the short-type cultivars contained more ash than the tall cultivars in the dry season $(15.9 \%$ vs $10.9 \% ; P<0.05)$. 
Table 2. Concentrations (\% DM) of chemical components of 8 napiergrass cultivars in rainy and dry season.

\begin{tabular}{|c|c|c|c|c|c|c|c|c|c|c|c|c|}
\hline \multirow{2}{*}{ Cultivar } & \multicolumn{3}{|c|}{ Cellulose } & \multicolumn{3}{|c|}{ Hemicelluloses } & \multicolumn{3}{|c|}{ Lignin } & \multicolumn{3}{|c|}{ Ash } \\
\hline & Leaf & Stem & Total & Leaf & Stem & Total & Leaf & Stem & Total & Leaf & Stem & Total \\
\hline \multicolumn{13}{|c|}{ A. Rainy season (August 2008) } \\
\hline DW & $32.7^{\mathrm{a}}$ & $45.8^{\mathrm{ab}}$ & $35.4^{\mathrm{c}}$ & $24.6^{\mathrm{a}}$ & $16.6^{\mathrm{a}}$ & $23.0^{\mathrm{ab}}$ & $5.6^{\mathrm{b}}$ & $5.7^{\mathrm{c}}$ & $5.6^{\mathrm{c}}$ & $10.0^{\mathrm{a}}$ & $10.1^{\mathrm{a}}$ & $10.0^{\mathrm{a}}$ \\
\hline ML & $37.8^{\mathrm{a}}$ & $36.8^{\mathrm{b}}$ & $37.4^{\mathrm{c}}$ & $27.3^{\mathrm{a}}$ & $25.1^{\mathrm{a}}$ & $26.4^{\mathrm{a}}$ & $6.9^{\mathrm{ab}}$ & $7.4^{\mathrm{c}}$ & $7.1^{\mathrm{c}}$ & $11.8^{\mathrm{a}}$ & $11.3^{\mathrm{a}}$ & $11.6^{\mathrm{a}}$ \\
\hline $\mathrm{BN}$ & $37.8^{\mathrm{a}}$ & $47.9^{\mathrm{ab}}$ & $44.1^{\mathrm{ab}}$ & $26.7^{\mathrm{a}}$ & $19.0^{\mathrm{a}}$ & $21.9^{\mathrm{ab}}$ & $8.1^{\mathrm{a}}$ & $11.0^{\mathrm{c}}$ & $9.9^{\mathrm{b}}$ & $8.2^{\mathrm{a}}$ & $10.0^{\mathrm{a}}$ & $9.3^{\mathrm{a}}$ \\
\hline TW & $34.9^{\mathrm{a}}$ & $46.5^{\mathrm{ab}}$ & $42.3^{\mathrm{b}}$ & $27.6^{\mathrm{a}}$ & $20.6^{\mathrm{a}}$ & $23.1^{\mathrm{ab}}$ & $9.1^{\mathrm{a}}$ & $12.0^{\mathrm{ab}}$ & $11.0^{\mathrm{ab}}$ & $10.1^{\mathrm{a}}$ & $6.4^{\mathrm{a}}$ & $7.7^{\mathrm{a}}$ \\
\hline $\mathrm{CM}$ & $36.7^{\mathrm{a}}$ & $48.3^{\mathrm{ab}}$ & $44.4^{\mathrm{ab}}$ & $26.4^{\mathrm{a}}$ & $19.8^{\mathrm{a}}$ & $22.1^{\mathrm{ab}}$ & $7.9^{\mathrm{ab}}$ & $13.3^{\mathrm{ab}}$ & $11.5^{\mathrm{ab}}$ & $10.5^{\mathrm{a}}$ & $11.5^{\mathrm{a}}$ & $11.2^{\mathrm{a}}$ \\
\hline WW & $37.8^{\mathrm{a}}$ & $49.2^{\mathrm{ab}}$ & $44.8^{\mathrm{ab}}$ & $27.6^{\mathrm{a}}$ & $19.4^{\mathrm{a}}$ & $22.6^{\mathrm{ab}}$ & $8.5^{\mathrm{a}}$ & $11.2^{\mathrm{b}}$ & $10.2^{\mathrm{b}}$ & $11.0^{\mathrm{a}}$ & $7.6^{\mathrm{a}}$ & $8.9^{\mathrm{a}}$ \\
\hline $\mathrm{TT}$ & $36.0^{\mathrm{a}}$ & $52.6^{\mathrm{a}}$ & $47.3^{\mathrm{a}}$ & $26.4^{\mathrm{a}}$ & $15.9^{\mathrm{a}}$ & $19.3^{\mathrm{b}}$ & $8.8^{\mathrm{a}}$ & $13.9^{\mathrm{a}}$ & $12.3^{\mathrm{a}}$ & $10.1^{\mathrm{a}}$ & $7.2^{\mathrm{a}}$ & $8.1^{\mathrm{a}}$ \\
\hline KS & $37.6^{\mathrm{a}}$ & $46.6^{\mathrm{ab}}$ & $43.5^{\mathrm{ab}}$ & $25.7^{\mathrm{a}}$ & $18.7^{\mathrm{a}}$ & $21.2^{\mathrm{ab}}$ & $9.0^{\mathrm{a}}$ & $13.0^{\mathrm{ab}}$ & $11.6^{\mathrm{ab}}$ & $9.4^{\mathrm{a}}$ & $9.9^{\mathrm{a}}$ & $9.7^{\mathrm{a}}$ \\
\hline \multicolumn{13}{|c|}{ B. Dry season (February 2009) } \\
\hline DW & $33.4^{\mathrm{b}}$ & $37.2^{\mathrm{c}}$ & $34.4^{\mathrm{d}}$ & $22.9^{\mathrm{bc}}$ & $24.9^{\mathrm{a}}$ & $23.4^{\mathrm{ab}}$ & $4.6^{\mathrm{a}}$ & $3.5^{\mathrm{d}}$ & $4.4^{\mathrm{c}}$ & $16.1^{\mathrm{a}}$ & $16.2^{\mathrm{a}}$ & $16.1^{\mathrm{a}}$ \\
\hline ML & $39.1^{\mathrm{a}}$ & $37.9^{\mathrm{bc}}$ & $38.5^{c}$ & $22.3^{c}$ & $21.6^{\text {abcd }}$ & $21.9^{\mathrm{bc}}$ & $5.2^{\mathrm{a}}$ & $4.1^{\mathrm{cd}}$ & $4.6^{\mathrm{c}}$ & $14.5^{\mathrm{a}}$ & $16.9^{\mathrm{a}}$ & $15.7^{\mathrm{a}}$ \\
\hline $\mathrm{BN}$ & $40.2^{\mathrm{a}}$ & $45.5^{\mathrm{a}}$ & $43.9^{\mathrm{ab}}$ & $30.6^{\mathrm{a}}$ & $19.9^{\mathrm{bcd}}$ & $23.0^{\mathrm{ab}}$ & $4.3^{\mathrm{a}}$ & $5.4^{\mathrm{cd}}$ & $5.1^{\mathrm{c}}$ & $10.0^{\mathrm{c}}$ & $11.5^{\mathrm{bc}}$ & $11.0^{\mathrm{b}}$ \\
\hline TW & $38.6^{\mathrm{a}}$ & $43.8^{\mathrm{ab}}$ & $42.6^{\mathrm{b}}$ & $27.8^{\mathrm{ab}}$ & $23.9^{\mathrm{ab}}$ & $24.8^{\mathrm{ab}}$ & $5.8^{\mathrm{a}}$ & $6.0^{\mathrm{bc}}$ & $6.0^{\mathrm{bc}}$ & $10.7^{\mathrm{bc}}$ & $10.3^{\mathrm{bc}}$ & $10.4^{\mathrm{b}}$ \\
\hline $\mathrm{CM}$ & $38.4^{\mathrm{a}}$ & $47.6^{\mathrm{a}}$ & $45.3^{\mathrm{ab}}$ & $27.9^{\mathrm{ab}}$ & $23.0^{\mathrm{abc}}$ & $24.2^{\mathrm{ab}}$ & $5.7^{\mathrm{a}}$ & $7.9^{\mathrm{ab}}$ & $7.3^{\mathrm{ab}}$ & $10.6^{\mathrm{bc}}$ & $9.6^{\mathrm{C}}$ & $9.9^{\mathrm{b}}$ \\
\hline WW & $40.0^{\mathrm{a}}$ & $42.9^{\mathrm{abc}}$ & $43.1^{\mathrm{ab}}$ & $27.7^{\mathrm{ab}}$ & $23.7^{\mathrm{ab}}$ & $25.9^{\mathrm{a}}$ & $5.1^{\mathrm{a}}$ & $4.4^{\mathrm{cd}}$ & $4.7^{\mathrm{C}}$ & $10.4^{\mathrm{c}}$ & $12.7^{\mathrm{a}}$ & $11.9^{\mathrm{b}}$ \\
\hline $\mathrm{TT}$ & $39.1^{\mathrm{a}}$ & $48.9^{\mathrm{a}}$ & $46.7^{\mathrm{a}}$ & $24.4^{\mathrm{bc}}$ & $18.0^{\mathrm{d}}$ & $19.5^{c}$ & $6.7^{\mathrm{a}}$ & $8.1^{\mathrm{ab}}$ & $7.8^{\mathrm{a}}$ & $12.3^{\mathrm{b}}$ & $10.6^{\mathrm{bc}}$ & $11.0^{\mathrm{b}}$ \\
\hline KS & $38.2^{\mathrm{a}}$ & $47.1^{\mathrm{a}}$ & $44.6^{\mathrm{ab}}$ & $28.3^{\mathrm{ab}}$ & $19.2^{\mathrm{cd}}$ & $21.7^{\mathrm{bc}}$ & $5.2^{\mathrm{a}}$ & $8.8^{\mathrm{a}}$ & $7.8^{\mathrm{a}}$ & $11.7^{\mathrm{bc}}$ & $10.9^{\mathrm{bc}}$ & $11.1^{\mathrm{b}}$ \\
\hline
\end{tabular}

${ }^{\mathrm{abc}}$ Within columns in the same season, different superscripts indicate significant differences between cultivars $(P<0.05)$.

Table 3. Element content (\% DM), energy content (MJ/kg) and energy production (GJ/ha) of 8 napiergrass cultivars in rainy and dry season.

\begin{tabular}{|c|c|c|c|c|c|c|c|c|c|c|c|}
\hline \multirow{2}{*}{ Cultivar } & \multicolumn{5}{|c|}{ Element $^{1 /}$} & \multicolumn{3}{|c|}{ Energy content $^{1 /}$} & \multicolumn{3}{|c|}{ Energy production $^{2 /}$} \\
\hline & $\mathrm{C}$ & $\mathrm{H}$ & $\mathrm{O}$ & $\mathrm{N}$ & $\mathrm{S}$ & Leaf & Stem & Whole & Leaf & Stem & Whole \\
\hline \multicolumn{12}{|c|}{ A. Rainy season (August 2008) } \\
\hline DW & $39.0^{\mathrm{d}}$ & $4.5^{\mathrm{c}}$ & $54.3^{\mathrm{a}}$ & $2.0^{\mathrm{a}}$ & $0.2^{\mathrm{a}}$ & $15.11^{\mathrm{b}}$ & $14.44^{\mathrm{c}}$ & $14.98^{\mathrm{b}}$ & 78.44 & 19.86 & 98.38 \\
\hline ML & $39.7^{\mathrm{cd}}$ & $4.7^{\mathrm{bc}}$ & $53.7^{\mathrm{ab}}$ & $1.7^{\mathrm{a}}$ & $0.2^{\mathrm{a}}$ & $15.82^{\mathrm{ab}}$ & $14.39^{c}$ & $15.27^{\mathrm{b}}$ & 68.26 & 42.32 & 110.81 \\
\hline $\mathrm{BN}$ & $43.3^{\mathrm{a}}$ & $4.9^{\mathrm{ab}}$ & $50.6^{\mathrm{d}}$ & $1.0^{\mathrm{b}}$ & $0.2^{\mathrm{a}}$ & $16.40^{\mathrm{a}}$ & $16.07^{\mathrm{ab}}$ & $16.19^{\mathrm{a}}$ & 84.13 & 136.68 & 220.81 \\
\hline TW & $40.8^{\mathrm{bc}}$ & $4.8^{\mathrm{ab}}$ & $53.1^{\mathrm{abc}}$ & $1.1^{\mathrm{b}}$ & $0.2^{\mathrm{a}}$ & $16.54^{\mathrm{ab}}$ & $16.15^{\mathrm{ab}}$ & $16.07^{\mathrm{a}}$ & 87.06 & 151.54 & 235.18 \\
\hline WW & $39.8^{\mathrm{cd}}$ & $4.7^{\mathrm{bc}}$ & $54.2^{\mathrm{a}}$ & $1.1^{\mathrm{b}}$ & $0.2^{\mathrm{a}}$ & $15.94^{\mathrm{ab}}$ & $15.94^{\mathrm{b}}$ & $15.94^{\mathrm{a}}$ & 85.76 & 131.63 & 217.38 \\
\hline $\mathrm{TT}$ & $41.6^{\mathrm{b}}$ & $4.8^{\mathrm{ab}}$ & $52.4^{\mathrm{bc}}$ & $1.0^{\mathrm{b}}$ & $0.2^{\mathrm{a}}$ & $16.57^{\mathrm{a}}$ & $16.28^{\mathrm{a}}$ & $16.36^{\mathrm{a}}$ & 90.17 & 192.42 & 282.44 \\
\hline KS & $41.5^{\mathrm{b}}$ & $5.0^{\mathrm{a}}$ & $52.3^{c}$ & $1.0^{\mathrm{b}}$ & $0.2^{\mathrm{a}}$ & $16.53^{\mathrm{a}}$ & $16.07^{\mathrm{ab}}$ & $16.23^{\mathrm{a}}$ & 63.06 & 114.57 & 176.70 \\
\hline \multicolumn{12}{|c|}{ B. Dry season (February 2009) } \\
\hline DW & $35.8^{\mathrm{b}}$ & $5.7^{\mathrm{b}}$ & $56.3^{\mathrm{ab}}$ & $2.0^{\mathrm{a}}$ & $0.07^{\mathrm{a}}$ & $14.27^{\mathrm{b}}$ & $13.64^{\text {cd }}$ & $14.10^{\mathrm{d}}$ & 48.19 & 11.09 & 59.09 \\
\hline ML & $35.8^{\mathrm{b}}$ & $5.7^{\mathrm{b}}$ & $56.8^{\mathrm{a}}$ & $1.7^{\mathrm{ab}}$ & $0.03^{\mathrm{b}}$ & $14.60^{\mathrm{b}}$ & $13.35^{\mathrm{d}}$ & $13.93^{\mathrm{d}}$ & 41.10 & 7.51 & 47.06 \\
\hline $\mathrm{BN}$ & $38.1^{\mathrm{a}}$ & $6.0^{\mathrm{a}}$ & $54.4^{\mathrm{bc}}$ & $1.5^{\mathrm{ab}}$ & $0.03^{\mathrm{b}}$ & $15.56^{\mathrm{a}}$ & $14.69^{\mathrm{ab}}$ & $14.94^{\mathrm{bc}}$ & 38.94 & 30.32 & 67.27 \\
\hline $\mathrm{CM}$ & $39.1^{\mathrm{a}}$ & $6.0^{\mathrm{a}}$ & $53.6^{\mathrm{c}}$ & $1.2^{\mathrm{b}}$ & $0.02^{\mathrm{b}}$ & $15.77^{\mathrm{a}}$ & $15.36^{\mathrm{a}}$ & $15.48^{\mathrm{a}}$ & 53.28 & 50.91 & 104.59 \\
\hline WW & $37.7^{\mathrm{a}}$ & $5.8^{\mathrm{ab}}$ & $54.9^{\mathrm{bc}}$ & $1.4^{\mathrm{b}}$ & $0.03^{\mathrm{b}}$ & $15.61^{\mathrm{a}}$ & $14.18^{\mathrm{bc}}$ & $14.64^{\mathrm{c}}$ & 44.91 & 29.28 & 71.45 \\
\hline $\mathrm{TT}$ & $37.7^{\mathrm{a}}$ & $5.9^{\mathrm{ab}}$ & $55.1^{\mathrm{bc}}$ & $1.5^{\mathrm{ab}}$ & $0.02^{\mathrm{b}}$ & $15.31^{\mathrm{a}}$ & $15.06^{\mathrm{a}}$ & $15.11^{\mathrm{abc}}$ & 50.77 & 50.88 & 98.86 \\
\hline $\mathrm{KS}$ & $38.6^{\mathrm{a}}$ & $6.0^{\mathrm{a}}$ & $54.1^{\mathrm{bc}}$ & $1.4^{\mathrm{b}}$ & $0.02^{\mathrm{b}}$ & $15.52^{\mathrm{a}}$ & $15.02^{\mathrm{a}}$ & $15.15^{\mathrm{ab}}$ & 42.72 & 35.70 & 77.69 \\
\hline
\end{tabular}

${ }^{1 / a b c}$ Within columns in the same season, different superscripts indicate significant differences between cultivars $(P<0.05)$; ${ }^{2 /}$ Calculation based on DMY of grass harvested in August 2008 (A) and February 2009 (B).

\subsection{Energy Content}

In both seasons, energy content of the taller cultivars exceeded that of the short-type cultivars for leaf, stem and whole plants $(P<0.05)$ (Table 3$)$. In the rainy season, Tifton had the highest energy content in leaf and stem, 16.57 and $16.28 \mathrm{MJ} / \mathrm{kg}$, respectively, as well as in whole plants (16.36 MJ/kg), while Common tended to produce the highest values in the dry season. When these were converted to energy yields per unit area, energy yields of the taller cultivars were much higher than those of the short-type cultivars. In the rainy season, Tifton produced $282 \mathrm{GJ} /$ ha while the two short-type cultivars produced about $100 \mathrm{GJ} / \mathrm{ha}$. Differences were not so great at the dry season harvest but taller cultivars still produced more energy per unit area than the short-type cultivars.

\subsection{Ethanol Yield}

Pretreatment with steam explosion apparatus increased glucose concentrations in all plant parts for all cultivars, but reduced the ethanol conversion efficiency (L/t DM) 
of leaf and increased the ethanol conversion efficiency of stem. As a result, theoretical ethanol yields $(\mathrm{kL} / \mathrm{ha})$ of the 6 tall cultivars were increased and that of the dwarf-type cultivars reduced by pretreatment. The conversion efficiency in pretreated material ranged from 347.5 to 463.9 L/t DM, compared with 340.1 - 431.0 L/t DM for untreated material. Theoretical ethanol yield was highest in Tifton followed by Common and Wruk wona regardless of pretreatment (Table 3).

\section{Discussion}

This study has provided valuable information on the potential of a range of cultivars of napiergrass for biofuel production in central Thailand. All of the taller cultivars produced high biomass yields over the course of the study and were far superior to the short-type cultivars (Dwarf and Muaklek) in terms of dry matter production. The 58 t/ha produced by Tifton and 52 t/ha by Wruk wona indicate that these cultivars represent potentially good sources of biomass for conversion to ethanol. This confirms results obtained by other workers $[6-8,13]$. The importance of soil moisture to plant growth was highlighted by the marked reduction of dry matter yields in the December-February period, when rainfall registrations were minimal. Supply of material during this period to support an ethanol plant would be an issue and supplementary irrigation might need to be considered to provide a constant supply of vegetative biomass. The issue of lower yields at this time was further complicated by the lower energy concentrations in material harvested at this time. Once adequate moisture was obtained, all grasses responded well to excellent temperatures for growth $\left(35^{\circ} \mathrm{C}-40^{\circ} \mathrm{C}\right)$ with biomass yields in May being generally the highest recorded at any harvest.

A strategy of harvesting in May, August and November, with no harvests in the dry season might be desirable, but the economics and logistics of closing the processing plant for a lengthy period would need to be considered. The importance of soil moisture to plant growth was highlighted by the marked reduction of dry matter yields in the December-February period, when rainfall registra- tions were minimal. Supply of material during this period to support an ethanol plant would be an issue and supplementary irrigation might need to be considered to provide a constant supply of vegetative biomass. The issue of lower yields at this time was further complicated by the lower energy concentrations in material harvested at this time. Once adequate moisture was obtained, all grasses responded well to excellent temperatures for growth $\left(35^{\circ} \mathrm{C}-40^{\circ} \mathrm{C}\right)$ with biomass yields in May being generally the highest recorded at any harvest. A strategy of harvesting in May, August and November, with no harvests in the dry season might be desirable, but the economics and logistics of closing the processing plant for a lengthy period would need to be considered.

It is known that grass can be converted into solid and liquid biofuels [7,14]. In the present study, the 6 talltyped napiergrass cultivars displayed a high potential to produce bioenergy through both combustion and fermentation systems (Tables 2 and 3). Chemical properties of biomass are critical in determining the suitability of the material for fuel production [15]. On average, concentrations of cell wall components (cellulose, hemicelluloses and lignin) in the harvested material during the rainy season reached the standards acceptable for biofuel production [16]. Concentrations of cellulose and lignin in Tifton were higher, and concentrations of hemicelluloses and ash were lower than in other cultivars, which resulted in the highest energy concentration of $16.36 \mathrm{MJ} / \mathrm{kg}$ in this cultivar (Table 3 ).

The main chemical elements affecting combustion quality showed seasonal variation, leading to seasonal differences in gross energy content in leaf and stem fractions (Table 3). Grass harvested in the rainy season displayed larger biomass yield as well as higher energy content than in the dry season.

The complexity of grass cell wall components is an obstacle to hydrolysis and enzymatic fermentation to produce ethanol [17]. Pretreatment of the biomass before hydrolysis can increase yield of fermentable sugar and improve the rate of enzyme hydrolysis of cellulose and hemicelluloses [18-21]. In this experiment (Table 4), the

Table 4. Glucose concentrations in harvested material and theoretical ethanol yield of 8 napiergrass cultivars of untreated and treated material by steam explosion in August 2008.

\begin{tabular}{|c|c|c|c|c|c|c|c|c|c|c|c|c|c|c|}
\hline \multirow{3}{*}{ Cultivar } & \multicolumn{7}{|c|}{ Untreated material } & \multicolumn{7}{|c|}{ Treated material } \\
\hline & \multicolumn{3}{|c|}{ 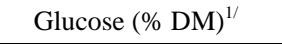 } & \multicolumn{3}{|c|}{ Ethanol efficiency (L/t) } & \multirow{2}{*}{$\begin{array}{c}\text { Ethanol } \\
\text { yield (kL/ha) }\end{array}$} & \multicolumn{3}{|c|}{ Glucose (\% DM) } & \multicolumn{3}{|c|}{ Ethanol efficiency (L/t) } & \multirow{2}{*}{$\begin{array}{c}\text { Ethanol } \\
\text { yield (kL/ha) }\end{array}$} \\
\hline & Leaf & Stem & Whole & Leaf & Stem & Whole & & Leaf & Stem & Whole & Leaf & Stem & Whole & \\
\hline ML & 42.2 & 39.2 & 41.0 & 483.0 & 353.1 & 431.0 & 3.13 & 54.0 & 73.8 & 62.7 & 355.8 & 492.4 & 410.5 & 2.98 \\
\hline $\mathrm{BN}$ & 39.5 & 48.6 & 45.2 & 412.2 & 324.0 & 357.5 & 4.87 & 49.5 & 63.0 & 59.1 & 325.1 & 424.7 & 386.9 & 5.27 \\
\hline TW & 38.0 & 52.9 & 47.5 & 405.0 & 303.6 & 340.1 & 4.97 & 46.4 & 72.3 & 57.6 & 303.9 & 417.9 & 376.9 & 5.51 \\
\hline WW & 43.4 & 48.3 & 46.4 & 441.7 & 347.8 & 384.5 & 5.24 & 53.2 & 67.5 & 63.0 & 349.4 & 452.3 & 412.2 & 5.62 \\
\hline $\mathrm{TT}$ & 38.3 & 52.8 & 48.1 & 472.8 & 330.4 & 376.0 & 6.49 & 50.5 & 72.3 & 67.0 & 333.5 & 487.9 & 438.5 & 7.56 \\
\hline KS & 37.0 & 53.9 & 47.9 & 455.3 & 317.9 & 366.0 & 3.98 & 48.6 & 69.6 & 63.1 & 321.4 & 461.4 & 412.4 & 4.49 \\
\hline
\end{tabular}

${ }^{1 /}$ There was no replication in glucose content or ethanol yield. 
improvement in ethanol conversion efficiency and ethanol production from napiergrass by pretreating the biomass demonstrated the benefit of this strategy. Ethanol conversion efficiency of the treated napiergrass biomass was similar to that of rice straw, bagasse and corn stover [12].

\section{Conclusion}

The results of the present study indicate the potential of tall napiergrass cultivars to produce biomass for conversion to ethanol and direct combustion in central Thailand to satisfy the increasing need for energy. Of the cultivars tested, Tifton seemed to show the most promising cultivar. Napiergrass is tropical forage, thus this findings can be applicable to other countries in the tropical region as well.

\section{Acknowledgements}

The authors wish to thank Mr Lyle Winks for his criticism and correcting the manuscript and the staff of Suwanvajokkasikit Research Station for their assistance. This research was financially supported by PTT Public Company Limited (PTT). Kannika Rengsirikul received the Golden Jubilee scholarship (TRF, Thailand).

\section{REFERENCES}

[1] EPPO, "Energy Statistics,” 2010. http://www.eppo.go.th/info/index.html

[2] DEDE, “Renewable Energy Development Plans,” 2010. http://61.19.246.165/ energy/redps.php?id=24

[3] M. Hoshino, "Studies on the Tropical Forage Crop in Thailand," Ministry of Agriculture and Forestry, Japan, 1975.

[4] S. Tudsri, S. T. Jorgensen, P. Riddach and A. Pookpakdi, "Effect of Cutting Height and Dry Season Closing Date on Yield and Quality of Five Napier Grass Cultivars in Thailand,” Tropical Grassland, Vol. 36, 2002, pp. 147148.

[5] T. Tekletsadis, S. Tudsri, S. Juntakool and S. Prasanpanich, "Effect of Dry Season Cutting Management on Subsequent Forage Yield and Quality of Ruzi (Brachiaria ruziziensis) and Dwarf Napier (Pennisetum purpureum) in Thailand," Kasetsart Journal, Vol. 40, 2004, pp. 159160.

[6] S. Ketkamalas, "Effect of Variety and Cutting Stage on Yield and Nutritive Value of Napier Silage,” M.Sc. Thesis, Kasetsart University, Bangkok, 2006 (in Thai).

[7] A. Prochnow, M. Heiermann, M. Plöchl, T. Amon and P. J. Hobbs, "Bioenergy from Permanent Grassland-A Review: 2. Combustion,” Bioresource Technology, Vol. 100, No. 21, 2009, pp. 4945-4954. doi:10.1016/j.biortech.2009.05.069

[8] S. N. Naik, V. V. Goud, P. K. Rout and A. K. Dalai, "Production of First and Second Generation Biofuels: A Comprehensive Review,” Renewable and Sustainable En- ergy Reviews, Vol. 14, No. 2, 2010, pp. 578-597. doi:10.1016/j.rser.2009.10.003

[9] AOAC, "Official Methods of Analysis of the Association of Official Analytical Chemists,” 18th Edition, Association of Official Analytical Chemists, Washington DC, 2005.

[10] OMAF, “Official Methods of Analysis of Fertilizer,” Japan, 1987.

[11] H. K. Goering and P. J. Van Soest, "Forage Fiber Analyses (Apparatus, Reagents, Procedures, and Some Applications)," Agriculture Handbook No. 379, United States Department of Agriculture, 1970.

[12] US Department of Energy, "Theoretical Ethanol Yield Calculation,” 2009.

http://1.eere.energy.gov/biomass/ethanol_yield_calculator .htm

[13] L. Khairani, Y. Ishii, S. Idota, R. F. Utamy and A. Nishiwaki, "Variation in Growth Attributes, Dry Matter Yield and Quality among 6 Genotypes of Napier Grass Used for Biomass in Year of Establishment in Southern Kyushu, Japan,” Asian Journal of Agricultural Research, 2012. doi:ajar.0000.50058.50058

[14] J. S. Yuan, K. H. Tiller, H. Al-Ahmad, N. R. Stewart and C. N. Stewart Jr., "Plants to Power: Bioenergy to Fuel the Future," Trends in Plant Science, Vol. 13, No. 8, 2008, pp. 421-429. doi:10.1016/j.tplants.2008.06.001

[15] I. Obernberger, T. Brunner and G. Bärnthaler, "Chemical Properties of Solid Biofuels-Significance and Impact," Biomass and Bioenergy, Vol. 30, No. 11, 2006, pp. 973982. doi:10.1016/j.biombioe.2006.06.011

[16] I. Lewandowski and A. Kicherer, "Combustion Quality of Biomass: Practical Relevance and Experiments to Modify the Biomass Quality of Miscanthus giganteus,” European Journal of Agronomy, Vol. 6, No. 3-4, 1997, pp. 163-177. doi:10.1016/S1161-0301(96)02044-8,

[17] M. Pauly and K. Keegstra, "Cell-Wall Carbohydrates and Their Modification as a Resource for Biofuels,” The Plant Journal, Vol. 54, No. 4, 2008, pp. 559-568. doi:10.1111\%2fj.1365-313X.2008.03463.x

[18] B. Toussaint, G. Excoffier and M. R. Vignon, "Effect of Steam Explosion Treatment on the Physio-Chemical Characteristics and Enzyme Hydrolysis of Poplar Cell Wall Components," Animal Feed Science and Technology, Vol. 32, No. 1-3, 1991, pp. 235-242. doi:10.1016/0377-8401(91)90028-Q,

[19] C. Cara, E. Ruiz, M. Ballesteros, P. Manzanares, M. J. Negro and E. Castro, "Production of Fuel Ethanol from Steam-Explosion Pretreated Olive Tree Pruning," Fuel, Vol. 87, No. 6, 2008, pp. 692-700. doi:10.1016/j.fuel.2007.05.008

[20] L. H. Zhang, D. Li, L. J. Wang, T. P. Wang, L. Zhang, X. D. Chen and Z. H. Mao, "Effect of Steam Explosion on Biodegradation of Lignin in Wheat Straw," Bioresource Technology, Vol. 99, No. 17, 2008, pp. 8512-8515. doi:10.1016/j.biortech.2008.03.028

[21] A. T. W. M. Hendriks and G. Zeeman, "Pretreatments to Enhance the Digestibility of Lignocellulosic Biomass," Bioresource Technology, Vol. 100, No. 1, 2009, pp. 1018. doi: 10.1016/j.biortech.2008.05.027 